\title{
Inequalities in air pollution exposure are increasing in the United States
}

\author{
Abdulrahman Jbaily ${ }^{\mathrm{a}}$, Xiaodan Zhou ${ }^{\mathrm{b}}$, Jie Liu $^{\mathrm{b}}$, Ting-Hwan Lee ${ }^{\mathrm{b}}$, Stéphane Verguet ${ }^{\mathrm{a}}$, Francesca Dominici ${ }^{\mathrm{c}, *}$ \\ ${ }^{a}$ Department of Global Health and Population, Harvard T.H. Chan School of Public Health, Boston, MA, USA \\ ${ }^{b}$ Environmental Systems Research Institute, Redlands, CA, USA \\ ${ }^{c}$ Department of Biostatistics, Harvard T.H. Chan School of Public Health, Boston, USA
}

\begin{abstract}
Exposure to ambient air pollution contributes substantially to the global burden of disease, and in 2015, ambient exposure to $\mathrm{PM}_{2.5}$ (fine particles with a mass median aerodynamic diameter of less than $2.5 \mu \mathrm{m}$ ) was the fifth-ranking risk factor of mortality globally. We analyzed data from the US zip code tabulation areas $(\mathrm{N}=32047)$ for 2000-2016 and found strong evidence of inequalities in exposure to $\mathrm{PM}_{2.5}$ among both racial/ethnic and income groups. Most alarming, we found that these inequalities have been increasing over time. From 2010 to 2016 inequalities in the exposure to $\mathrm{PM}_{2.5}$ levels above $8 \mu \mathrm{g} / \mathrm{m}^{3}$ across racial/ethnic, and income groups increased by factors of 1.6 and 4.0 respectively. As shown in our powerful map visualizations, these results indicate that air pollution regulations must not only decrease $\mathrm{PM}_{2.5}$ concentration levels nationwide but also prioritize reducing environmental injustice across the US.
\end{abstract}

Strong associations exist between exposure to $\mathrm{PM}_{2.5}$ (fine particles with a mass median aerodynamic diameter of less than $2.5 \mu \mathrm{m}$ ) in the US and adverse health outcomes such as hospital admissions [1, 2, 3, 4] and mortality $[5,6,7,8,9,10]$. It is well documented that minorities and people of low socioeconomic status in the US are at a higher risk of death from being exposed to $\mathrm{PM}_{2.5}[11,12,13,14]$. Although inequalities in air pollution exposure among racial/ethnic and socioeconomic groups in the US are known to exist $[15,16,17,18]$, it is unknown whether these inequalities are being addressed. Here we provide strong and concerning evidence that although air pollution in the US has decreased over the years, disparities among racial/ethnic populations and socioeconomic groups have increased. We found that Black populations and lower income groups are exposed to the highest levels of particulate matter across the study period and that inequalities in exposure to particulate matter among racial/ethnic communities have doubled between 2010 and 2016. Our findings have strong and time-sensitive implications on policies set by the US Environmental Protection Agency (EPA) to combat racial injustice and the higher death toll of COVID-19 among minorities.

\section{Disparities in air pollution exposure among racial/ethnic groups}

The US EPA is required to reexamine its National Ambient Air Quality Standards (NAAQS) every five years. In 2012 the EPA set the NAAQS for $\mathrm{PM}_{2.5}$ to $12 \mu \mathrm{g} / \mathrm{m}^{3}$ [19]. On average across the US, we found that $\mathrm{PM}_{2.5}$ has decreased by $43 \%$ (Animation 1 in supplementary material; and Extended Data figure A.1). We also found that the percentage of the population exposed to $\mathrm{PM}_{2.5}$ levels higher than $12 \mu \mathrm{g} / \mathrm{m}^{3}$ decreased from $62.8 \%$ in 2000 to $0.23 \%$ in 2016 (map shown in Extended Data figure A.2).

For each racial/ethnic group (White, Black, Asian, and Hispanic) ${ }^{1}$, we construct a map that shows only zip code tabulation areas (ZCTAs) where the race/ethnicity is most present ${ }^{2}$. Figures $1 \mathrm{a}$ and $1 \mathrm{~b}$ show the $\mathrm{PM}_{2.5}$ distribution on

\footnotetext{
*Email: fdominic@hsph.harvard.edu

${ }^{1}$ Native American was not included in the animation as regions of presence are very small and difficult to visualize. It was included in the main analysis.

${ }^{2}$ In the case of the White population for example, we use the White population fraction of the ZCTA population to compute the average White population fraction across all ZCTAs $(\approx 84.2 \%)$. We then set the margin at $84 \%$ and only show ZCTAs with a White population fraction exceeding this margin. The margin for the Black population was computed similarly (7.6\%) and set at $7 \%$.
} 
medRxiv preprint doi: https://doi.org/10.1101/2020.07.13.20152942; this version posted July 15, 2020. The copyright holder for this preprint

(which was not certified by peer review) is the author/funder, who has granted medRxiv a license to display the preprint in perpetuity.

It is made available under a CC-BY-NC-ND 4.0 International license .

the constructed Black and White population maps for 2000 and 2016, respectively. We found that the Black ZCTAs (left map) are dominated by high $\mathrm{PM}_{2.5}$ concentrations relative to the White ZCTAs (right map) in both 2000 and 2016. Furthermore, we see a steeper decline in $\mathrm{PM}_{2.5}$ among the White ZCTAs as compared to the Black ZCTAs. Similar maps for the Asian and Hispanic groups are shown in Extended Data figure A.3 and Animation 2 in supplementary material.

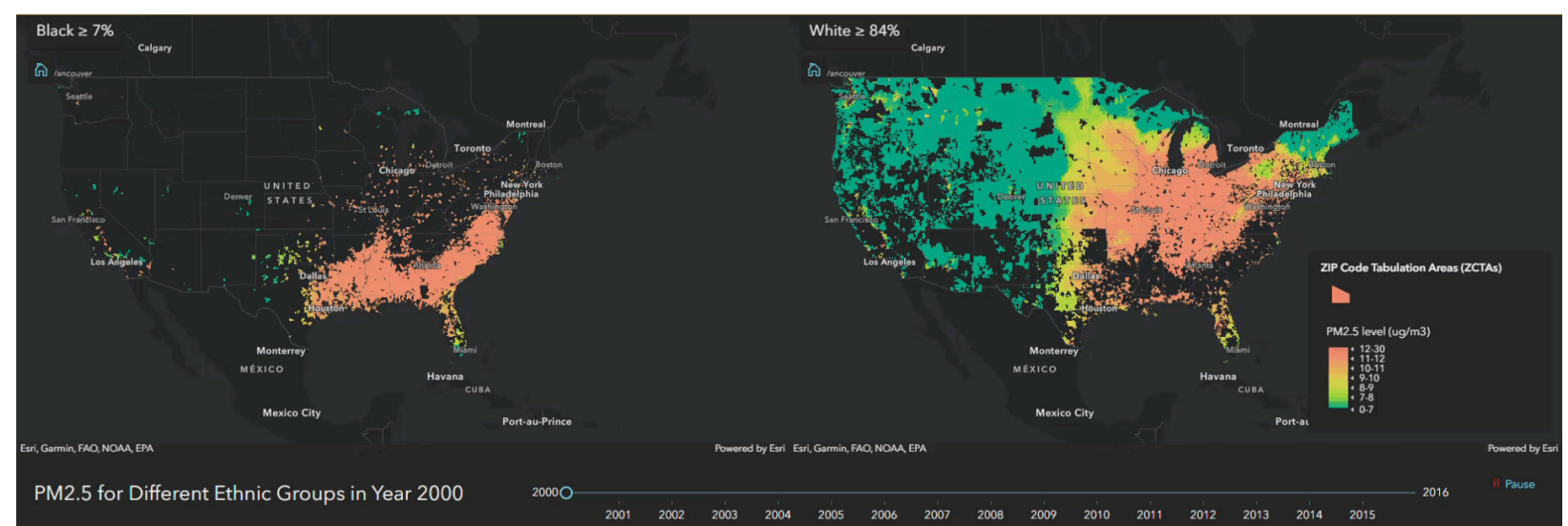

(a) $\mathrm{PM}_{2.5}$ concentrations in 2000 in ZCTAs with the Black population exceeding $7 \%$ of the total ZCTA population (left) and in ZCTAs with the White population exceeding $84 \%$ of the total ZCTA population (right)

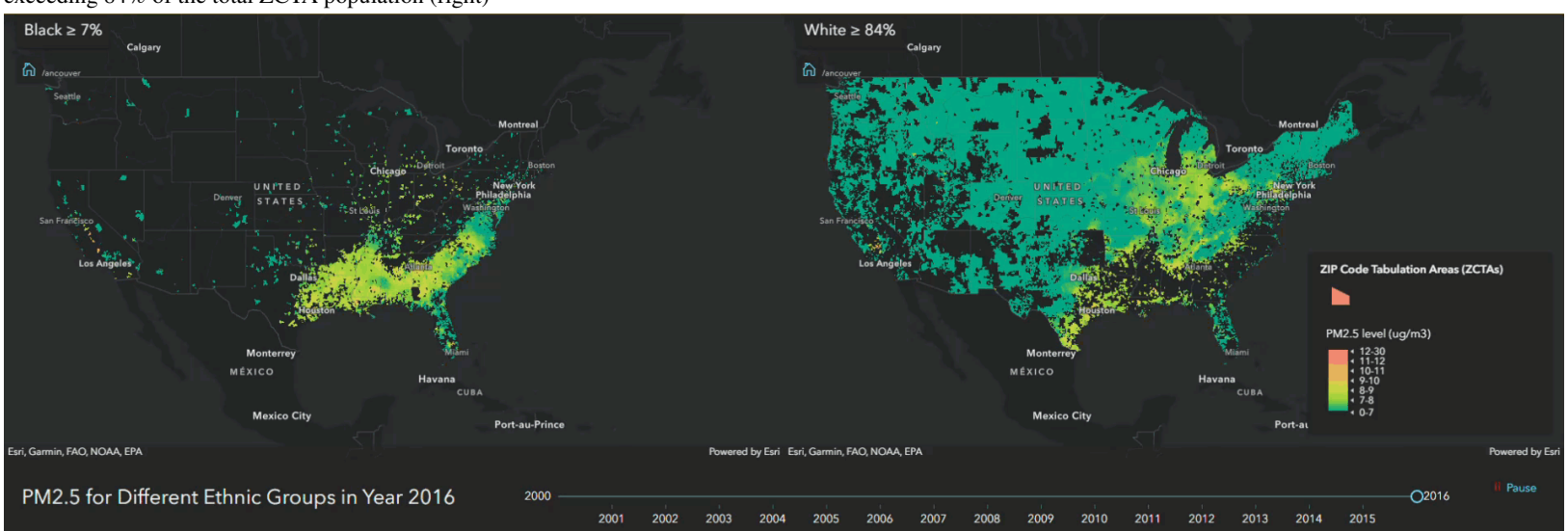

(b) $\mathrm{PM}_{25}$ concentrations in 2016 in ZCTAs with the Black population exceeding 7\% of the total ZCTA population (left) and in ZCTAs with the White population exceeding $84 \%$ of the total ZCTA population (right)

Figure 1: We use the White population fraction of the ZCTA population to compute the average White population fraction (aWpf) across all ZCTAs $(\approx 84 \%)$. Similarly, we compute the average Black population fraction $(\mathrm{aBpf})(\approx 7 \%)$. The maps in panel (a) show $\mathrm{PM}_{2.5}$ levels for the year 2000 in ZCTAs with a Black population fraction above aBpf (left) and in ZCTAs with a White population fraction aWpf (right). High $\mathrm{PM}_{2.5}$ concentrations exist in almost all ZCTAs with a Black population above aBpf, while a wide range of low and high $\mathrm{PM}_{2.5}$ concentrations exist in ZCTAs with a White population above aWpf in 2000. Panel (b) shows the same information for the year 2016. It can be visually seen that a larger decrease in $\mathrm{PM}_{2.5}$ concentrations from 2000 to 2016 occurred in ZCTAs corresponding to the White population (right map of panel b). Similar maps of the Hispanic and Asian populations for 2000 and 2016 are shown in Extended Data figures A.3a and A.3b and Animation 2 in supplementary material.

To quantify these differences in exposure, we compute the population-weighted average $\mathrm{PM}_{2.5}$ concentration for every racial/ethnic population (please see Methods) (Extended Data figure A.4a). For all years, we found that the Black population is exposed to higher levels of $\mathrm{PM}_{2.5}$ compared to other racial/ethnic groups. To visualize this finding for 2016, we illustrate how the population-weighted $\mathrm{PM}_{2.5}$ average concentration changes as ZCTAs become more populated by a certain race/ethnicity (Extended Data figure A.4b). We found that as the Black population increases in a ZCTA, the $\mathrm{PM}_{2.5}$ concentration consistently increases and a very steep incline is seen for ZCTAs with more than $85 \%$ of their population as Black. The trend of the Hispanic population follows that of the Black population except at population fractions above $85 \%$. The opposite is seen for White populations; $\mathrm{PM}_{2.5}$ concentration decreases as density of the White population increases in ZCTAs; a steep decrease is shown for ZCTAs with a White population 
fraction exceeding 70\%. Further, in ZCTAs where the population of Native Americans is at least $80 \%$, the average $\mathrm{PM}_{2.5}$ concentration drops to below $4 \mu \mathrm{g} / \mathrm{m}^{3}$. When the Asian population size increases there is no notable change in the average $\mathrm{PM}_{2.5}$ concentration.

\section{Disparities in air pollution exposure among income groups}

Disparities exist among distinct income groups, with low-income groups exposed to the highest $\mathrm{PM}_{2.5}$ concentrations. We assign all ZCTAs percentile ranks from 1 to 100 based on median household income and categorize them into ten income groups. We designate the lowest and highest three income groups as low-income and high-income respectively and then split the US map into two maps - ZCTAs defined as low- and high-income (please see Methods). We visualize the $\mathrm{PM}_{2.5}$ concentration distribution on the two maps for 2000 to 2016 (Animation 3 in supplementary material). The low-income map appears to be dominated by an overall higher concentration of $\mathrm{PM}_{2.5}$ as compared to the high-income map especially in recent years. We include snapshots of 2000 and 2016 (figure 2). In 2016 for example, $\sim 80 \%$ of ZCTAs of the high-income US map had $\mathrm{PM}_{2.5}$ concentrations lower than $8 \mu \mathrm{g} / \mathrm{m}^{3}$ compared to only $\sim 70 \%$ of the ZCTAs of the low-income map (figure $2 \mathrm{~b}$ ). We summarize the contents of the maps by computing the average $\mathrm{PM}_{2.5}$ concentration for the low- and high-income groups (Extended Data figure A.5); the $\mathrm{PM}_{2.5}$ concentration is consistently higher for the low-income group, except in 2001. Further, we isolate the effects of income on the disparities among the racial/ethnic groups in Extended Data figures A.6a and A.6b.

\section{Racial and income inequalities in exposure to air pollution are increasing}

We found that although air pollution in the US has decreased, inequality in breathing polluted air has increased among the different racial/ethnic and income groups. To visualize this finding, for each year and for each race, we ranked the US ZCTAs from the least dense to the most dense with respect to that race $^{3}$ (Extended Data figure A.7a). For example, in figure 3a the dark blue region on the Black population map contains the ZCTAs with the highest ratio of Black population to total ZCTA population, and the light yellow region contains the ZCTAs with the lowest ratio of Black population to total ZCTA population. Similarly, the White population map in figure 3a contains dark blue and light yellow regions that correspond to high and low White population proportions respectively. In figure $3 \mathrm{a}$, we only show for the Black and White populations the ZCTAs with a $\mathrm{PM}_{2.5}$ concentration higher than $8 \mu \mathrm{g} / \mathrm{m}^{3}$ for the year 2010 (i.e. high pollution ZCTAs). This figure reveals that almost half of these high pollution ZCTAs are where the Black population is concentrated (southern part of the map as indicated by the dark blue region on the Black population US map), and the other half is where the White population is concentrated (northern part of the map as indicated by the dark blue region on the White population US map). However, reexamining the high pollution ZCTAs for 2016 (figure 3b) shows that only those with concentrated Black populations remain above the $\mathrm{PM}_{2.5}$ threshold (majority of the Black population map is dark blue and that of the White population map is light yellow). In summary, air pollution reduction regulations between 2010 and 2016 were enforced and attained in the areas dominated by the White populations whereas the Black populations are still living with high $\mathrm{PM}_{2.5}$ levels; this clearly indicates an increase in disparities to air pollution exposure among the White and Black populations as will be numerically shown later. Additionally, we extend figure 3 to include the Hispanic and Asian populations and present the results in Extended Data figures A.7b and A.7c. We also repeat the same visualization for thresholds different than $8 \mu \mathrm{g} / \mathrm{m}^{3}$ and present them in Animation 4 in Supplementary Material, which shows the distribution of the different racial/ethnic communities across multiple $\mathrm{PM}_{2.5}$ concentrations for 2010 and 2016.

Furthermore, we quantify such variation in disparities to air pollution exposure among racial/ethnic (and income) groups using the coefficient of variation $\operatorname{CoV}$ (please see Methods) and summarize our findings in figure 4. For example, interpreting the figures for 2010 and 2016 (shown in figures $3 \mathrm{a}$ and $3 \mathrm{~b}$ ), we find that $75 \%$ of the population was exposed to $\mathrm{PM}_{2.5}$ levels higher than $8 \mu \mathrm{g} / \mathrm{m}^{3}$ in 2010, whereas only $36 \%$ in 2016 (solid blue line). However, the $C o V$ shows that the variation in air pollution exposure among racial/ethnic groups relative to its mean increased from 0.17

\footnotetext{
${ }^{3}$ Ranking the ZCTAs for a particular race is done by using the population fraction of the race in every ZCTA to split them into 100 quantiles by using percentiles.
} 
medRxiv preprint doi: https://doi.org/10.1101/2020.07.13.20152942; this version posted July 15, 2020. The copyright holder for this preprint (which was not certified by peer review) is the author/funder, who has granted medRxiv a license to display the preprint in perpetuity. It is made available under a CC-BY-NC-ND 4.0 International license.

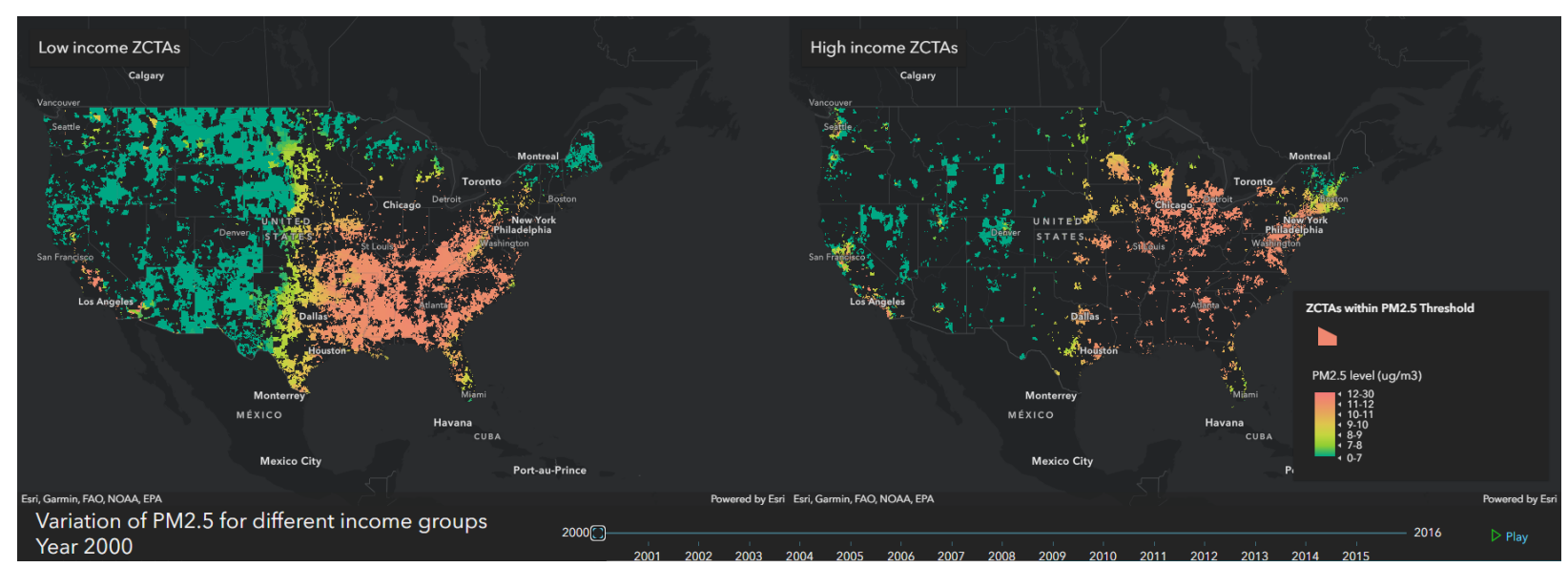

(a) $\mathrm{PM}_{2.5}$ concentrations in 2000 in low-income (left) and high-income (right) ZCTAs.

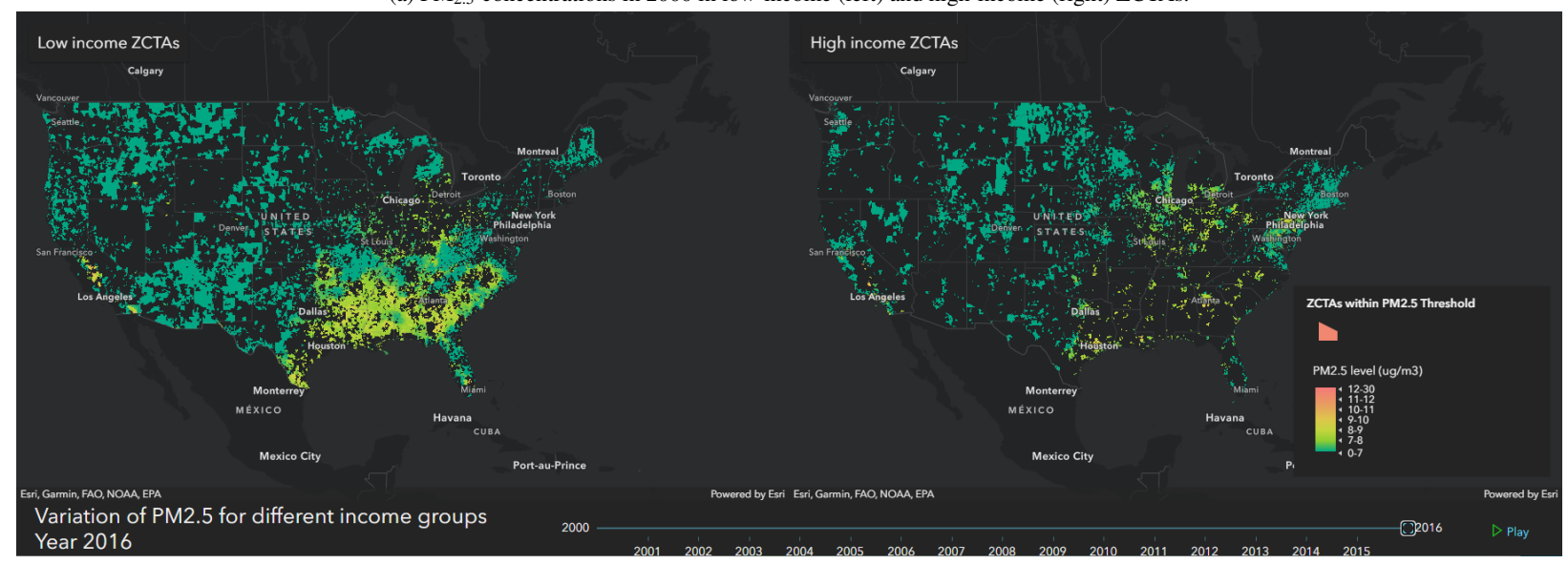

(b) $\mathrm{PM}_{2.5}$ concentrations in 2016 in low-income (left) and high-income (right) ZCTAs.

Figure 2: We assign all ZCTAs percentile ranks from 1 to 100 based on median household income and categorize them into ten income groups. We designate the lowest and highest three income groups as low-income and high-income respectively. The maps in panel (a) show $\mathrm{PM}_{2.5}$ levels for the year 2000 in low-income (left) and high-income (right) ZCTAs. Panel (b) shows the same information for the year 2016. Disparities in exposure to $\mathrm{PM}_{2.5}$ among the two groups are apparent and it can be visually seen that a larger decrease in $\mathrm{PM}_{2.5}$ concentrations from 2000 to 2016 occurred in high-income ZCTAs (Animation 3 in supplementary material).

in 2010 to 0.27 in 2016, which shows that exposure disparities among racial/ethnic groups have increased by a factor of 1.58. This is in agreement with figure 3. It is interesting to note that inequality in exposure to $\mathrm{PM}_{2.5}$ levels above $8 \mu \mathrm{g} / \mathrm{m}^{3}$ remained constant between 2010 and 2014, and started to increase in 2015. Figure 4a shows the analysis for a threshold $T=10 \mu \mathrm{g} / \mathrm{m}^{3}$, which reveals greater inequalities. The analysis is also applied for the case of the ten income groups instead of the racial/ethnic groups (figure $4 \mathrm{~b}$ ). We observe that inequality in exposure to $\mathrm{PM}_{2.5}$ levels above $10 \mu \mathrm{g} / \mathrm{m}^{3}$ across income groups decreased from 2010 to 2013 and then started to increase. Further, the level of inequality among income groups as measured by $\mathrm{CoV}$ is smaller than that observed among racial/ethnic groups.

In addition to using the easily interpretable $\mathrm{CoV}$, we repeated the inequality analysis of figure 4 using the Atkinson index, an alternative inequality metric used in the literature [16, 20,21]. These findings are located in Extended Data figure A. 8 and are similar to those of figure 4 which confirms the increase in disparities in exposure to air pollution among racial/ethnic groups and among income groups. 
medRxiv preprint doi: $h$ ttps://doi.org/10.1101/2020.07.13.20152942; this version posted July 15, 2020. The copyright holder for this preprint (which was not certified by peer review) is the author/funder, who has granted medRxiv a license to display the preprint in perpetuity. It is made available under a CC-BY-NC-ND 4.0 International license .

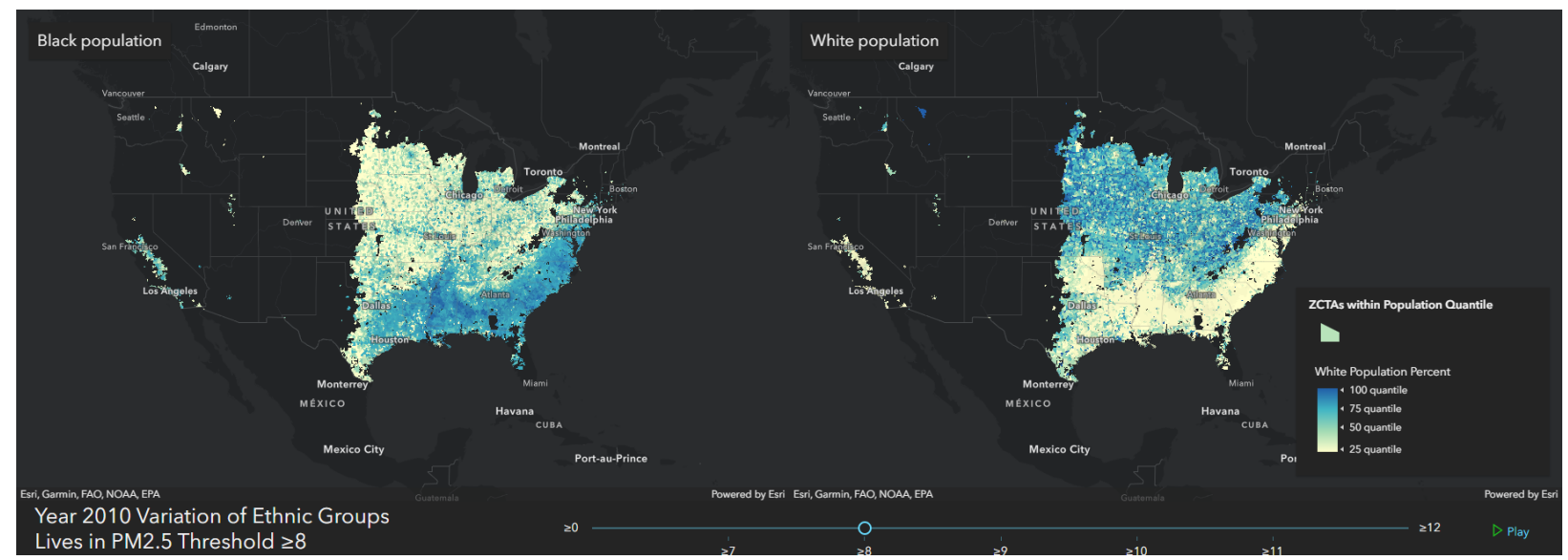

(a) Black population map in 2010 (left) and White population map in 2010 (right)

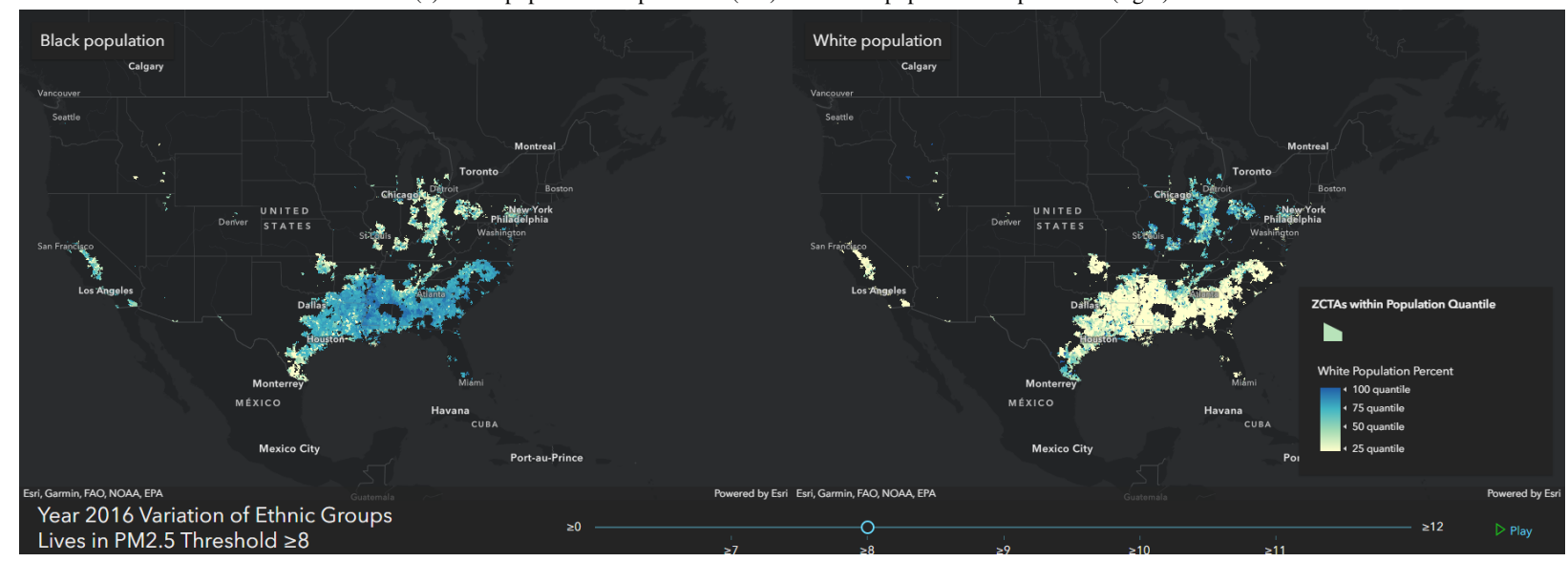

(b) Black population map in 2016 (left) and White population map in 2016 (right)

Figure 3: The maps only show US ZCTAs with $\mathrm{PM}_{2.5}$ levels above $8 \mu \mathrm{g} / \mathrm{m}^{3}$ in (a) 2010 and (b) 2016. We first focus on the maps on the left of the figure which correspond to the Black population. A color spectrum from light-yellow to dark-blue is used to color-code the ZCTAs, where the dark-blue and light-yellow colors correspond to ZCTAs with the largest and smallest Black population percentages of the total ZCTA population respectively, or equivalently where the Black population is most and least present respectively. The Black population map in panel (a) reveals that almost half of the ZCTAs with $\mathrm{PM}_{2.5}$ levels above $8 \mu \mathrm{g} / \mathrm{m}^{3}$ in 2010 correspond to those where the Black population most lives (almost half of the map is dark-blue). However in 2016, ZCTAs that remained above $8 \mu \mathrm{g} / \mathrm{m}^{3}$ are only those that are dominated by the Black population (Black population map in panel b). Similarly, the maps on the right of the figure correspond to the White population, where dark-blue and light-yellow colors corresponds to ZCTAs with the largest and smallest White population respectively. Contrary to the previous finding, ZCTAs that remained above $8 \mu \mathrm{g} / \mathrm{m}^{3}$ are only those where the White population is least present (White population map in panel b). This reveals that reduction in air pollution from 2010 to 2016 occurred in ZCTAs where the Black and White populations are least and most present respectively. Animation 4 shows the distribution of the different racial/ethnic communities across multiple ranges of $\mathrm{PM}_{2.5}$ concentrations in 2010 and 2016.

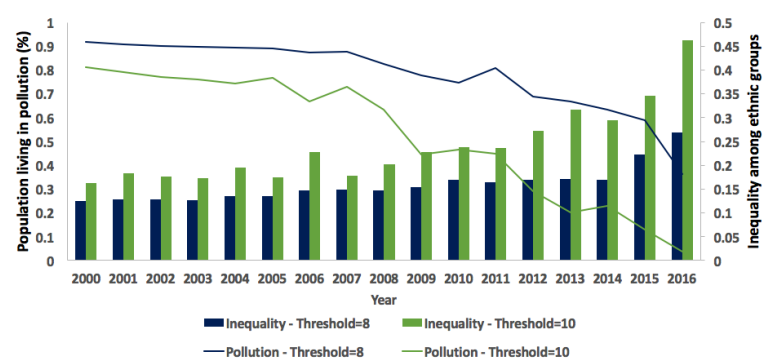

(a)

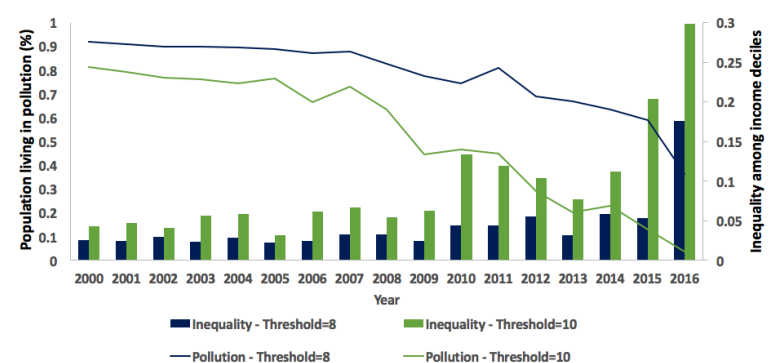

(b)

Figure 4: Inequality in exposure (as measured by $\mathrm{CoV}$ ) to $\mathrm{PM}_{2.5}$ concentrations above thresholds of 8 and $10 \mu \mathrm{g} / \mathrm{m}^{3}$ for 2000 to 2016 among (a) racial/ethnic groups (Black, White, Hispanic, Asian, and Native American) (b) and income groups (income deciles). The percentage of the US population living above the thresholds of 8 and $10 \mu \mathrm{g} / \mathrm{m}^{3}$ is also shown. The trend reveals that the decrease in air pollution has been accompanied by an increase in the disparities in exposure to air pollution among communities. 
medRxiv preprint doi: https://doi.org/10.1101/2020.07.13.20152942; this version posted July 15, 2020. The copyright holder for this preprint

(which was not certified by peer review) is the author/funder, who has granted medRxiv a license to display the preprint in perpetuity.

It is made available under a CC-BY-NC-ND 4.0 International license.

\section{Discussion}

We built a dataset that includes all US ZCTAs ${ }^{4}$ for 2000 to 2016 and contains demographic (median household income, racial/ethnic distribution, etc.) and pollution data ( $\mathrm{PM}_{2.5}$ concentrations) and investigated temporal patterns in $\mathrm{PM}_{2.5}$ levels and in air pollution exposure of racial/ethnic and income groups. $\mathrm{PM}_{2.5}$ concentrations decreased drastically from 2000 to 2016, where the population-weighted average of $\mathrm{PM}_{2.5}$ has decreased by $43 \%$ from the year $2000\left(13 \mu \mathrm{g} / \mathrm{m}^{3}\right)$ to $2016\left(7.3 \mu \mathrm{g} / \mathrm{m}^{3}\right)$. Further, it was evident that air pollution exposure disparities exist among both racial/ethnic and income groups. When investigating the air pollution exposure of the different racial/ethnic communities, we found that the Black population is consistently exposed to higher levels of $\mathrm{PM}_{2.5}$ on average. In 2016, the average $\mathrm{PM}_{2.5}$ concentration for the Black population was $11.6 \%$ higher than that of the White population and $28.6 \%$ higher than that of the Native American population. The Native American population was consistently exposed to the lowest levels of air pollution from 2000 to 2016 (Extended Data figure A.4a). Additionally, we found that as the Black population in ZCTAs increased, the average $\mathrm{PM}_{2.5}$ concentration increased; a steep increase was observed in ZCTAs where the Black population exceeded $85 \%$ of the population (Extended Data figure A.4b). Contrary to trends of the Black populations, the average $\mathrm{PM}_{2.5}$ concentration decreased as ZCTAs became more populated with the White and Native American populations (Extended Data figure A.4b). The analysis also showed that the low-income group consistently suffers from worse air conditions compared to higher-income groups. In 2016, the average low-income population $\mathrm{PM}_{2.5}$ concentration was $6.9 \%$ higher than that of the high-income population (Extended Data figure A.5). Of note, exposure disparities in racial/ethnic and income groups are related to geographical distribution. For example, the industrial nature of southern US may result in less strict pollution regulations and is more polluted. At the same time, southern states have higher Black and low income populations.

The most pertinent and concerning finding of our study is that even though air pollution has decreased, exposure disparities among both racial/ethnic groups and income groups (as measured by the coefficient of variation and Atkinson index) have increased. Indeed, figure 3 shows that air pollution reduction strategies from 2010 and 2016 mainly resulted in air pollution reduction in areas where the White population is most concentrated.

The results of increasing inequalities in air pollution exposure are timely and concerning at a time where the US is facing crises of racism, and health disparities in COVID-19 health outcomes. There is an emerging research area in the US and around the world that provides preliminary evidence that long-term air pollution exposure increases susceptibility to COVID-19 [22]. Furthermore, it has been documented that racial minorities have higher COVID-19 death rates $[23,24]$. The results of this paper show that the EPA must not only act to decrease nationwide $\mathrm{PM}_{2.5}$ concentration levels on average but must also devise air pollution reduction strategies to reduce pollution exposure of minority and low-income populations to address environmental injustice.

\section{References}

[1] F. Dominici, R. D. Peng, M. L. Bell, L. Pham, A. McDermott, S. L. Zeger, J. M. Samet, Fine particulate air pollution and hospital admission for cardiovascular and respiratory diseases, Jama 295 (10) (2006) 1127-1134.

[2] M. L. Bell, K. Ebisu, R. D. Peng, J. Walker, J. M. Samet, S. L. Zeger, F. Dominici, Seasonal and regional short-term effects of fine particles on hospital admissions in 202 us counties, 1999-2005, American journal of epidemiology 168 (11) (2008) 1301-1310.

[3] I. Kloog, F. Nordio, A. Zanobetti, B. A. Coull, P. Koutrakis, J. D. Schwartz, Short term effects of particle exposure on hospital admissions in the mid-atlantic states: a population estimate, PloS one 9 (2) (2014).

[4] M. A. Bravo, K. Ebisu, F. Dominici, Y. Wang, R. D. Peng, M. L. Bell, Airborne fine particles and risk of hospital admissions for understudied populations: effects by urbanicity and short-term cumulative exposures in 708 us counties, Environmental health perspectives 125 (4) (2017) 594-601.

[5] F. Dominici, A. McDermott, S. L. Zeger, J. M. Samet, National maps of the effects of particulate matter on mortality: exploring geographical variation., Environmental Health Perspectives 111 (1) (2003) 39-44.

[6] R. Beelen, O. Raaschou-Nielsen, M. Stafoggia, Z. J. Andersen, G. Weinmayr, B. Hoffmann, K. Wolf, E. Samoli, P. Fischer, M. Nieuwenhuijsen, et al., Effects of long-term exposure to air pollution on natural-cause mortality: an analysis of 22 european cohorts within the multicentre escape project, The Lancet 383 (9919) (2014) 785-795.

\footnotetext{
${ }^{4}$ Demographic data for multiple ZCTAs $(2.7 \%)$ were missing. As a result, these geographic areas were not included in the analysis or animations.
} 
medRxiv preprint doi: https://doi.org/10.1101/2020.07.13.20152942; this version posted July 15, 2020. The copyright holder for this preprint

(which was not certified by peer review) is the author/funder, who has granted medRxiv a license to display the preprint in perpetuity. It is made available under a CC-BY-NC-ND 4.0 International license .

[7] D. L. Crouse, P. A. Peters, P. Hystad, J. R. Brook, A. van Donkelaar, R. V. Martin, P. J. Villeneuve, M. Jerrett, M. S. Goldberg, C. A. Pope III, et al., Ambient pm2. 5, o3, and no2 exposures and associations with mortality over 16 years of follow-up in the canadian census health and environment cohort (canchec), Environmental health perspectives 123 (11) (2015) 1180-1186.

[8] M. Makar, J. Antonelli, Q. Di, D. Cutler, J. Schwartz, F. Dominici, Estimating the causal effect of fine particulate matter levels on death and hospitalization: Are levels below the safety standards harmful?, Epidemiology (Cambridge, Mass.) 28 (5) (2017) 627.

[9] Q. Di, L. Dai, Y. Wang, A. Zanobetti, C. Choirat, J. D. Schwartz, F. Dominici, Association of short-term exposure to air pollution with mortality in older adults, Jama 318 (24) (2017) 2446-2456.

[10] X. Wu, D. Braun, J. Schwartz, M. Kioumourtzoglou, F. Dominici, Evaluating the impact of long-term exposure to fine particulate matter on mortality among the elderly, Science Advances (2020) eaba5692.

[11] Q. Di, Y. Wang, A. Zanobetti, Y. Wang, P. Koutrakis, C. Choirat, F. Dominici, J. D. Schwartz, Air pollution and mortality in the medicare population, New England Journal of Medicine 376 (26) (2017) 2513-2522.

[12] M. L. Bell, A. Zanobetti, F. Dominici, Evidence on vulnerability and susceptibility to health risks associated with short-term exposure to particulate matter: a systematic review and meta-analysis, American journal of epidemiology 178 (6) (2013) 865-876.

[13] Y. Wang, L. Shi, M. Lee, P. Liu, Q. Di, A. Zanobetti, J. D. Schwartz, Long-term exposure to pm2. 5 and mortality among older adults in the southeastern us, Epidemiology (Cambridge, Mass.) 28 (2) (2017) 207.

[14] M.-A. Kioumourtzoglou, J. Schwartz, P. James, F. Dominici, A. Zanobetti, Pm2. 5 and mortality in 207 us cities: modification by temperature and city characteristics, Epidemiology (Cambridge, Mass.) 27 (2) (2016) 221.

[15] M. L. Bell, K. Ebisu, Environmental inequality in exposures to airborne particulate matter components in the united states, Environmental health perspectives 120 (12) (2012) 1699-1704.

[16] A. Rosofsky, J. I. Levy, A. Zanobetti, P. Janulewicz, M. P. Fabian, Temporal trends in air pollution exposure inequality in massachusetts, Environmental research 161 (2018) 76-86.

[17] I. Mikati, A. F. Benson, T. J. Luben, J. D. Sacks, J. Richmond-Bryant, Disparities in distribution of particulate matter emission sources by race and poverty status, American journal of public health 108 (4) (2018) 480-485.

[18] M. L. Miranda, S. E. Edwards, M. H. Keating, C. J. Paul, Making the environmental justice grade: the relative burden of air pollution exposure in the united states, International journal of environmental research and public health 8 (6) (2011) 1755-1771.

[19] US Environmental Protection Agency. Process of reviewing the National Ambient Air Quality Standards., Last Accessed: 2019-12-23. URL https: //www.epa.gov/criteria-air-pollutants/process-reviewing-national-ambient-air-quality-standards

[20] L. P. Clark, D. B. Millet, J. D. Marshall, National patterns in environmental injustice and inequality: outdoor no2 air pollution in the united states, PloS one 9 (4) (2014) e94431.

[21] J. I. Levy, S. M. Chemerynski, J. L. Tuchmann, Incorporating concepts of inequality and inequity into health benefits analysis, International journal for equity in health 5 (1) (2006) 2.

[22] X. Wu, R. C. Nethery, B. M. Sabath, D. Braun, F. Dominici, Exposure to air pollution and covid-19 mortality in the united states, medRxiv (2020).

[23] Racial Data Transparency - State COVID-19 data by race, John's Hopkins University and Medicine - Coronavirus Resource Center. Available: https://coronavirus.jhu.edu/data/racial-data-transparency [Last accessed: 11 July 2020].

[24] The coronavirus is infecting and killing black Americans at an alarmingly high rate, The Washington Post, 07 April 2020. Available: https://www.washingtonpost.com/nation/2020/04/07/coronavirus-is-infecting-killing-black-americans-an-alarmingly-high-ratepost-analysis-shows [Last accessed: 11 July 2020].

[25] Q. Di, I. Kloog, P. Koutrakis, A. Lyapustin, Y. Wang, J. Schwartz, Assessing pm2. 5 exposures with high spatiotemporal resolution across the continental united states, Environmental science \& technology 50 (9) (2016) 4712-4721.

[26] Q. Di, H. Amini, L. Shi, I. Kloog, R. Silvern, J. Kelly, M. B. Sabath, C. Choirat, P. Koutrakis, A. Lyapustin, et al., An ensemble-based model of pm2. 5 concentration across the contiguous united states with high spatiotemporal resolution, Environment international 130 (2019) 104909.

\section{Supplementary Material}

Supplementary material is available upon request from corresponding author.

\section{Data Availability}

Data will be made accessible through the publishing journal upon manuscript acceptance.

\section{Code Availability}

The code will be made accessible through the publishing journal upon manuscript acceptance. 
medRxiv preprint doi: https://doi.org/10.1101/2020.07.13.20152942; this version posted July 15, 2020. The copyright holder for this preprint

(which was not certified by peer review) is the author/funder, who has granted medRxiv a license to display the preprint in perpetuity.

It is made available under a CC-BY-NC-ND 4.0 International license .

\section{Acknowledgements}

The authors would like to thank Joel D. Schwartz for providing the air pollution data, Benjamin Sabbath for cleaning and preparing the datasets, and Lauren Bennett for comments and discussions. This work was supported financially by grants from the Health Effects Institute (4953- RFA14-3/16-4), National Institute of Health (DP2MD012722), National Institute of Health and Yale University (R01MD012769), National Institute of Health and National Institute of Environmental Health Sciences (R01 ES028033) and the Environmental Protection Agency (83587201-0).

\section{Author contributions}

AJ, SV and FD contributed to the study design. AJ led the research with supervision from FD. XZ, JL and THL prepared the map animations. AJ drafted the manuscript with support from XZ, JL, THL, SV and FD. All authors read and approved the final manuscript for submission.

\section{Competing interests}

The authors declare no competing interests.

\section{Methods}

Our dataset includes all US zip code tabulation $\operatorname{areas}^{5}$ (ZCTAs) for 2000 to 2016 (N=32047). For each ZCTA, we obtained demographic and socioeconomic variables from the US Census Bureau when available and used interpolation techniques (moving average) to determine those of the missing years. Variables of interest comprised median household income, proportions of Native Americans, Asian, White, Black, and Hispanic residents, and population density. For each year, we assigned all ZCTAs percentile ranks from 1 to 100 based on median household income and categorized them into ten income groups. Throughout the paper we use low-income and high-income to label the lowest three and highest three income groups respectively.

We also used previously in-house developed prediction models to estimate $\mathrm{PM}_{2.5}$ concentration levels on $1 \mathrm{~km}$ by $1 \mathrm{~km}$ nationwide grids $[25,26]$. These use a validated ensemble-based model, which integrates three machine learning (ML) algorithms including gradient boosting, neural network, and random forest. These ML algorithms used more than 100 predictor variables from satellite data, land-use terms, meteorological variables, and chemical transport model predictions. The ensemble-based model was calibrated using daily $\mathrm{PM}_{2.5}$ concentrations measured at 2,156 US EPA monitoring sites, with an average cross-validated $R^{2}$ of 0.86 and an unbiased slope, indicating excellent model performance. For each ZCTA we calculated the daily average $\mathrm{PM}_{2.5}$ based on all covered $1 \mathrm{~km}^{2}$ grid cells and then computed annual averages. The annual averages of $\mathrm{PM}_{2.5}$ levels for each ZCTA were included in the dataset. We built one dataset by combining the demographic and $\mathrm{PM}_{2.5}$ variables across all US ZCTAs for 2000 to 2016 . Our dataset analysis reveals time patterns in air pollution across the US and inequalities in exposure to air pollution among racial/ethnic and income groups. Dynamic animations are used to communicate our findings along with plots that summarize and clarify the information embedded in our visualizations.

We first defined a group population-weighted $\mathrm{PM}_{2.5}$ concentration, where a group can be an income group such as the first decile, or an ethnic group such as the Hispanic population. In the case of racial/ethnic groups, the populationweighted $\mathrm{PM}_{2.5}$ concentration in racial/ethnic group $k$ is given by:

$$
\overline{\mathrm{PM}}_{2.5 k}=\frac{\sum_{j} \mathrm{PM}_{2.5 j} p_{k, j}}{\sum_{j} p_{k, j}},
$$

\footnotetext{
${ }^{5}$ Demographic data for multiple ZCTAs (2.7\%) were missing. As a result, these geographic areas were not included in the analysis or animations.
} 
where summation occurs over all ZCTAs. $p_{k, j}$ is the number of people in racial group $k$ living in the ZCTA $j$, and $\mathrm{PM}_{2.5 j}$ is the $\mathrm{PM}_{2.5}$ level in the ZCTA $j$. In the case of income groups, the population-weighted $\mathrm{PM}_{2.5}$ concentration of income group $i$ is:

$$
\overline{\mathrm{PM}}_{2.5 i}=\frac{\sum_{j \in i} \mathrm{PM}_{2.5 j} p_{j}}{\sum_{j \in i} p_{j}},
$$

where summation occurs only over ZCTAs $j$ belonging to the income group $i . p_{j}$ is the total population of ZCTA $j$, and $\mathrm{PM}_{2.5 j}$ is the $\mathrm{PM}_{2.5}$ level in ZCTA $j$.

Additionally, we defined a second $\mathrm{PM}_{2.5}$-related variable $(q)$ and use it to quantify the level of inequality in exposure to $\mathrm{PM}_{2.5}$ concentrations among the different racial/ethnic or income groups. The variable $q$ is defined as the percentage of a population exposed to $\mathrm{PM}_{2.5}$ levels above a certain $\mathrm{PM}_{2.5}$ threshold $T$. We can calculate $q$ for specific population subgroups. For example, we can compute the percentage of the population in the highest income group that is exposed at $\mathrm{PM}_{2.5}$ levels above $T=12 \mu \mathrm{g} / \mathrm{m}^{3}$, or the percentage of a racial/ethnic group, such as Native Americans, exposed to $\mathrm{PM}_{2.5}$ levels above $T=8 \mu \mathrm{g} / \mathrm{m}^{3}$.

To measure the degree of inequality across racial/ethnic (or income) groups in exposure to $\mathrm{PM}_{2.5}$ concentrations above $T$ for a specific year, we first compute $q$ for every racial/ethnic (or income) group. We then compute the coefficient of variation $(\mathrm{CoV})$ defined as:

$$
\operatorname{CoV}=\frac{\sqrt{\operatorname{Var}(q)}}{\mu(q)},
$$

where $\operatorname{Var}$ is the variance of $q$ and $\mu$ is the mean of $q$. $C o V$ measures the variability of a series of numbers independent of the data magnitude, so it captures the variation in $q$ among racial/ethnic (or income) groups in a given year relative to the mean pollution levels during that year.

For example, consider three years $Y_{1}, Y_{2}$ and $Y_{3}$, where the percentages of five racial/ethnic groups being exposed to $\mathrm{PM}_{2.5}$ levels above a threshold $T$ are, respectively:

$$
q_{1}=(11 \%, 13 \%, 14 \%, 15 \%, 17 \%) \quad q_{2}=(10 \%, 12 \%, 14 \%, 16 \%, 18 \%) \quad q_{3}=(1 \%, 1.2 \%, 1.4 \%, 1.6 \%, 1.8 \%)
$$

From $Y_{1}$ to $Y_{2}$, the coefficient of variation increases from $C o V_{1}=0.143$ to $\operatorname{CoV}_{2}=0.202$, which indicates that the variation in exposure to air pollution relative to the mean, and equivalently disparities among the racial/ethnic groups, increased by a factor of 1.4. On the other hand, although the pollution levels decreased drastically between $Y_{2}$ and $Y_{3}$ as can be seen by the different orders of magnitude of $q_{2}$ and $q_{3}$, the coefficient of variation is unchanged $\left(\mathrm{CoV}_{3}=0.202\right)$ indicating that the inequalities in exposure to air pollution among the racial/ethnic groups is the same between $Y_{2}$ and $Y_{3}$. These examples highlight the power of using $C o V$ to capture relative variation in the data independently of its magnitude. This is very important for our application because the level of pollution changes considerably over the years.

The outlined procedure of quantifying inequality through $C o V$ can be applied for any $\mathrm{PM}_{2.5}$ threshold $T$ and can be repeated for all years to track the evolution of inequality in exposure to air pollution among the different racial/ethnic (or income) groups. 
medRxiv preprint doi: https://doi.org/10.1101/2020.07.13.20152942; this version posted July 15,2020 . The copyright holder for this preprint (which was not certified by peer review) is the author/funder, who has granted medRxiv a license to display the preprint in perpetuity.

It is made available under a CC-BY-NC-ND 4.0 International license.

\section{Appendices}

\section{A. Extended Data Figures}

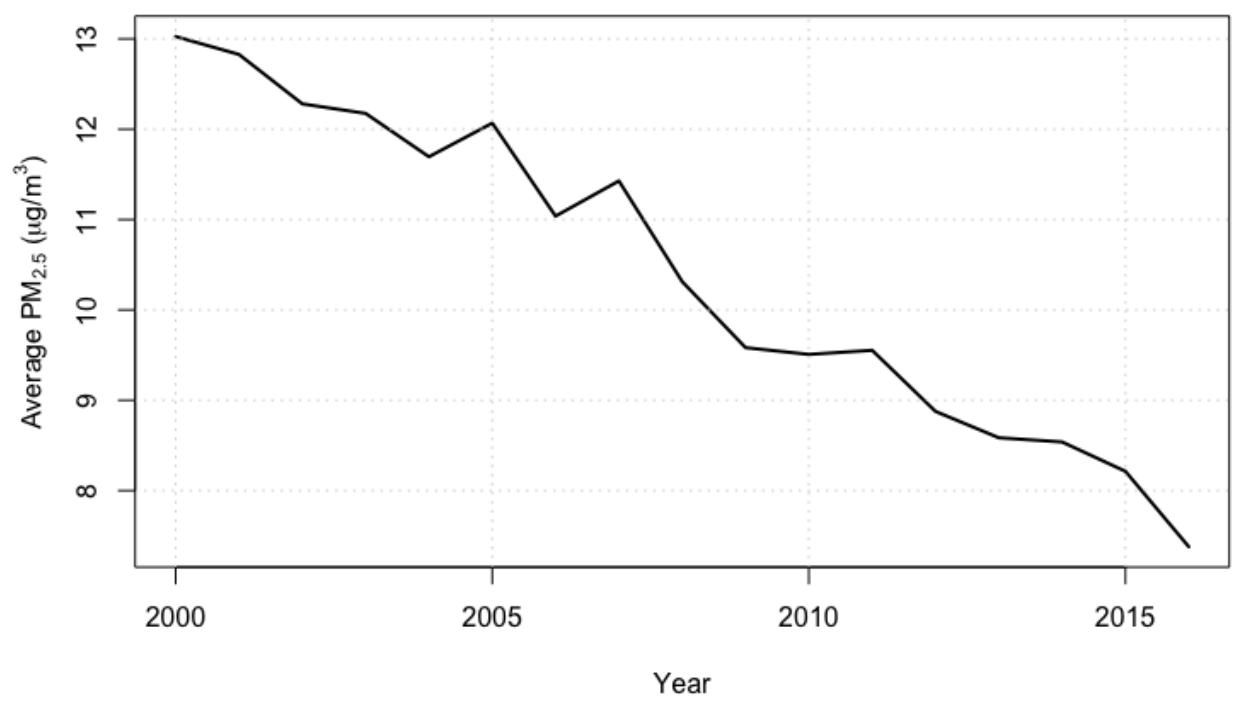

Figure A.1: The national average $\mathrm{PM}_{2.5}$ level has been decreasing in the US since 2000. 
medRxiv preprint doi: https://doi.org/10.1101/2020.07.13.20152942; this version posted July 15, 2020. The copyright holder for this preprint (which was not certified by peer review) is the author/funder, who has granted medRxiv a license to display the preprint in perpetuity.

It is made available under a CC-BY-NC-ND 4.0 International license.

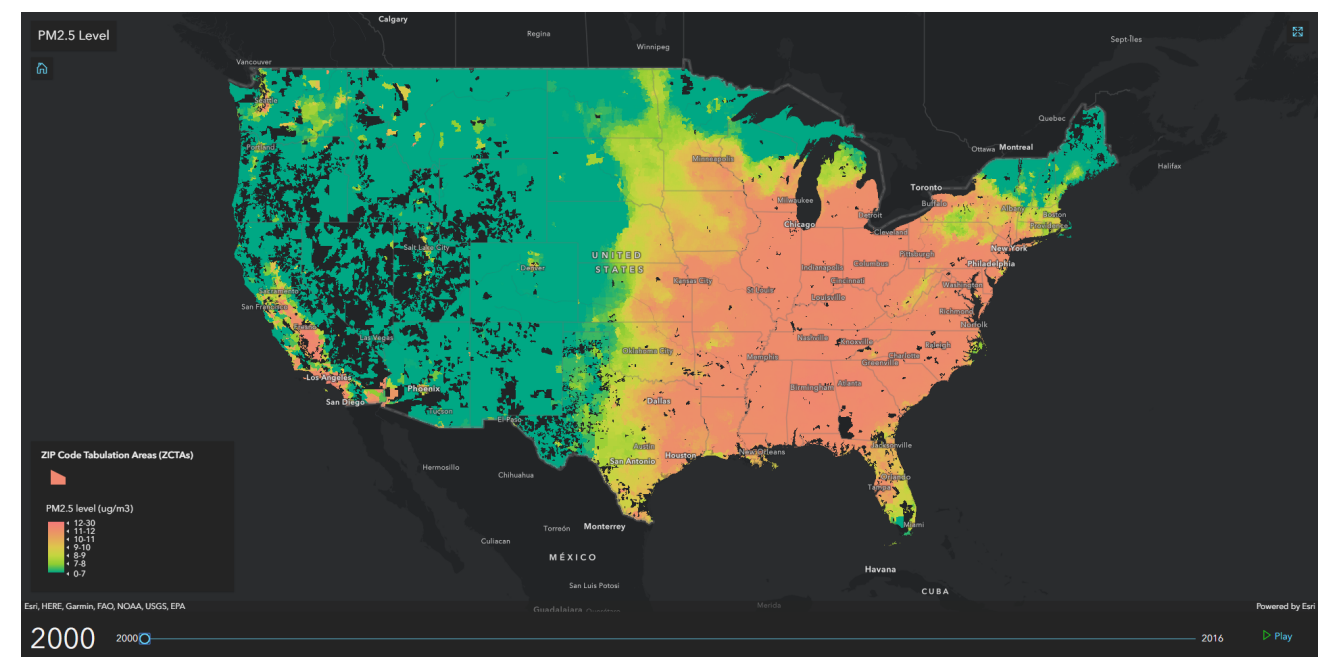

(a)

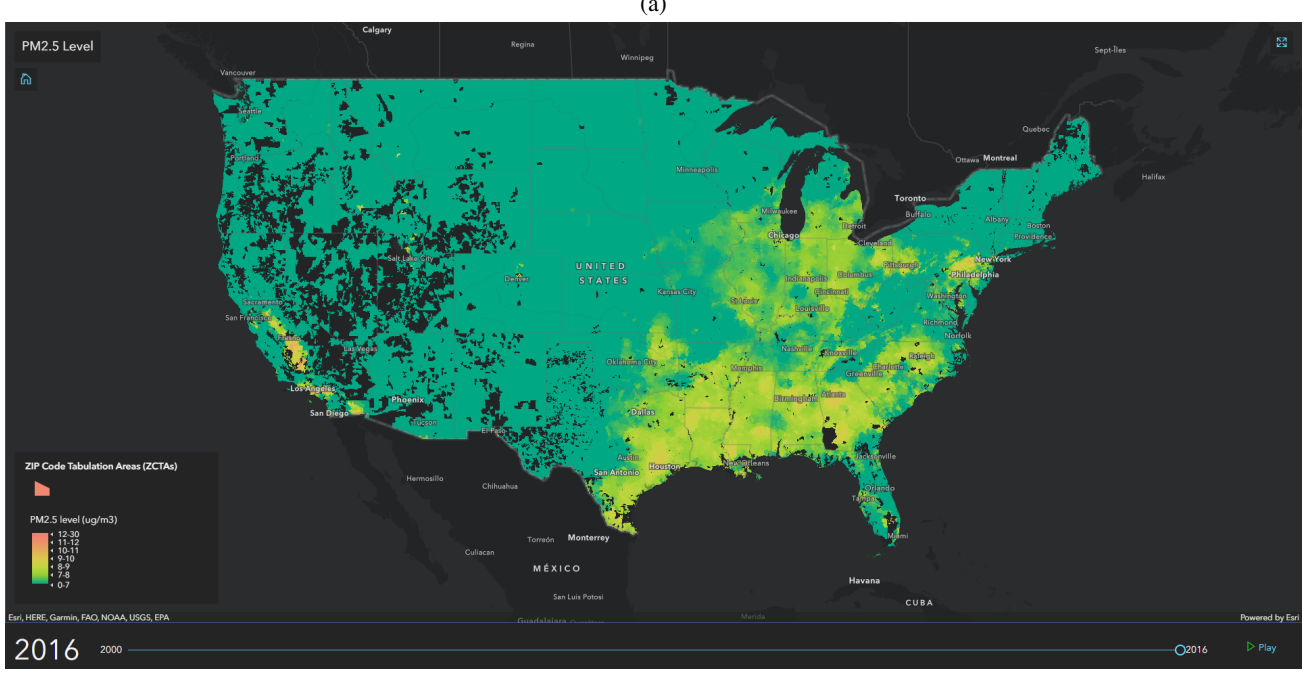

(b)

Figure A.2: Distribution of $\mathrm{PM}_{2.5}$ concentration levels in (a) 2000 and (b) 2016. We also include an animation that shows the distribution of $\mathrm{PM}_{2.5}$ concentration levels in the US from 2000 to 2016. (Animation 1) 
medRxiv preprint doi: https://doi.org/10.1101/2020.07.13.20152942; this version posted July 15, 2020. The copyright holder for this preprint (which was not certified by peer review) is the author/funder, who has granted medRxiv a license to display the preprint in perpetuity.

It is made available under a CC-BY-NC-ND 4.0 International license.

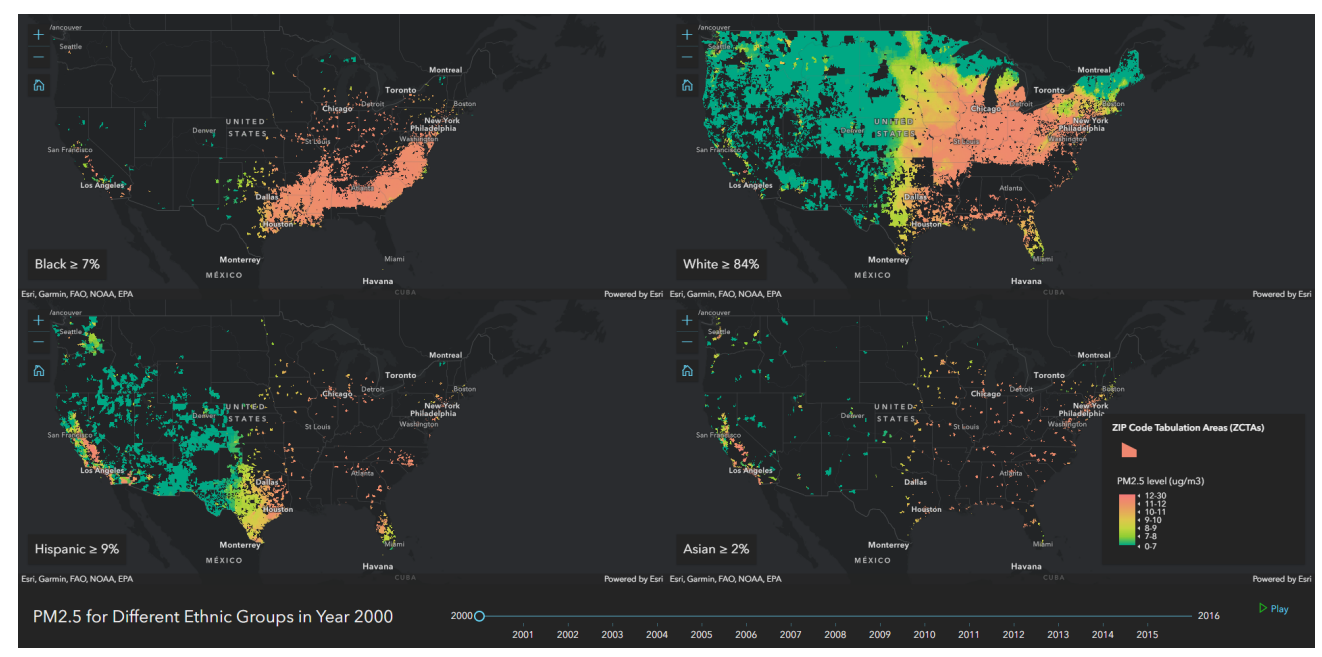

(a)

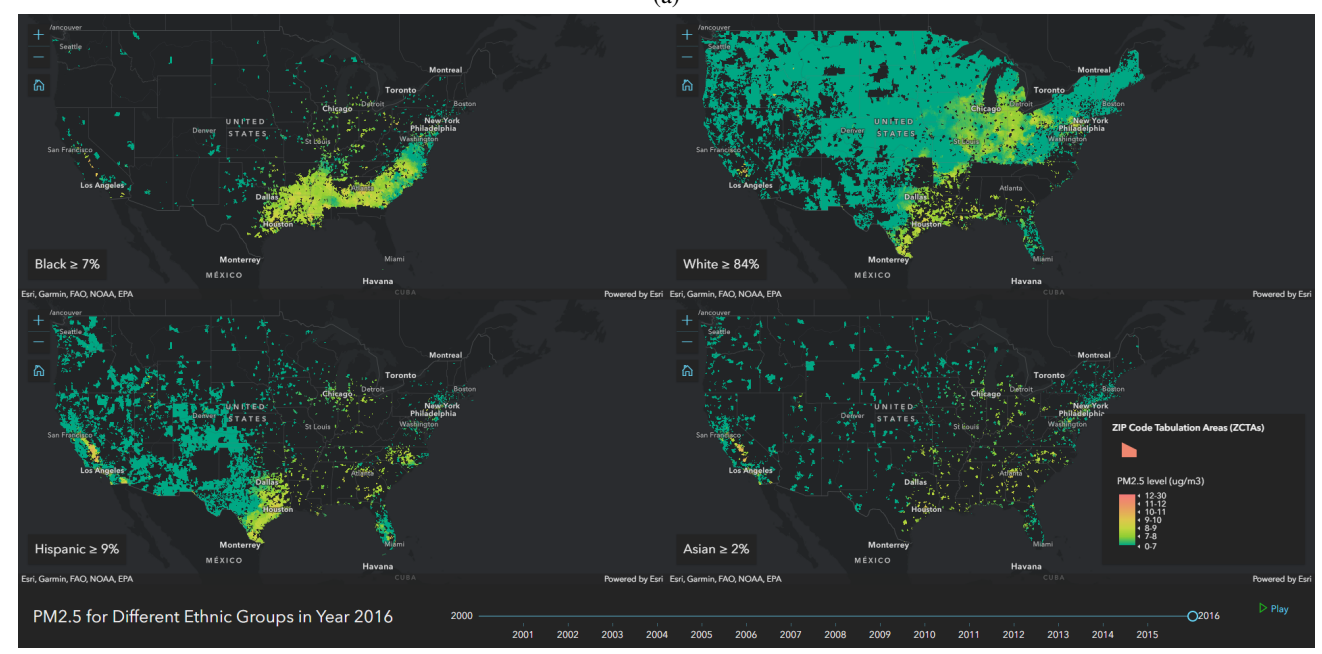

(b)

Figure A.3: Distribution of $\mathrm{PM}_{2.5}$ across four different maps each corresponding to a race/ethnicity for (a) 2000 and (b) 2016. (Animation 2) 
medRxiv preprint doi: https://doi.org/10.1101/2020.07.13.20152942; this version posted July 15, 2020. The copyright holder for this preprint (which was not certified by peer review) is the author/funder, who has granted medRxiv a license to display the preprint in perpetuity. It is made available under a CC-BY-NC-ND 4.0 International license .

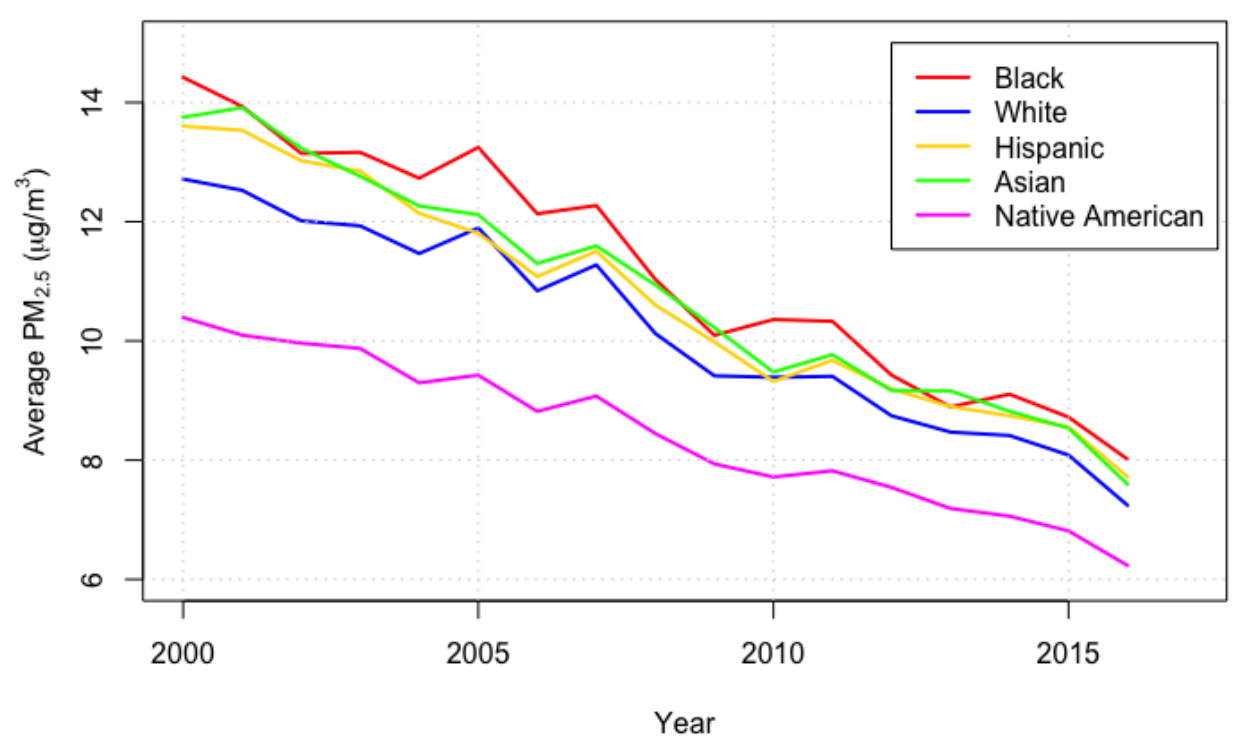

(a)

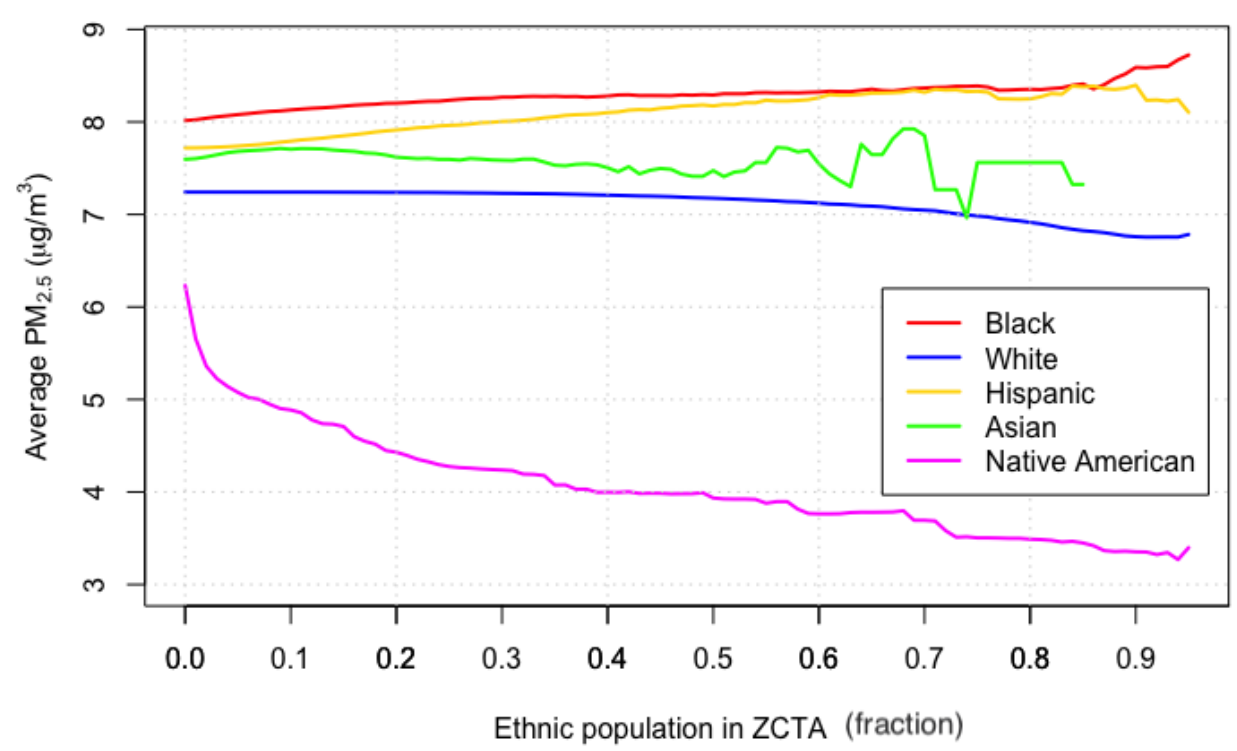

(b)

Figure A.4: (a) The population-weighted $\mathrm{PM}_{2.5}$ average concentration across the different racial/ethnic communities for 2000 to 2016 . The $\mathrm{PM}_{2.5}$ concentration across the racial/ethnic communities demonstrates that Black and Native American populations live in the most and least polluted areas respectively. (b) The population-weighted $\mathrm{PM}_{2.5}$ average concentration across racial/ethnic communities as a function of ZCTA racial/ethnic population (\%) for 2016 . When the racial/ethnic population \% is equal to 0.2 , the red curve includes every ZCTA where the Black population is $20 \%$ or more, and the blue curve includes every ZCTA where the White population is $20 \%$ or more. As ZCTA's Black and Hispanic populations increase, the $\mathrm{PM}_{2.5}$ concentration levels increase. The opposite effect is seen for the White and Native American communities. 
medRxiv preprint doi: https://doi.org/10.1101/2020.07.13.20152942; this version posted July 15, 2020. The copyright holder for this preprint (which was not certified by peer review) is the author/funder, who has granted medRxiv a license to display the preprint in perpetuity.

It is made available under a CC-BY-NC-ND 4.0 International license.

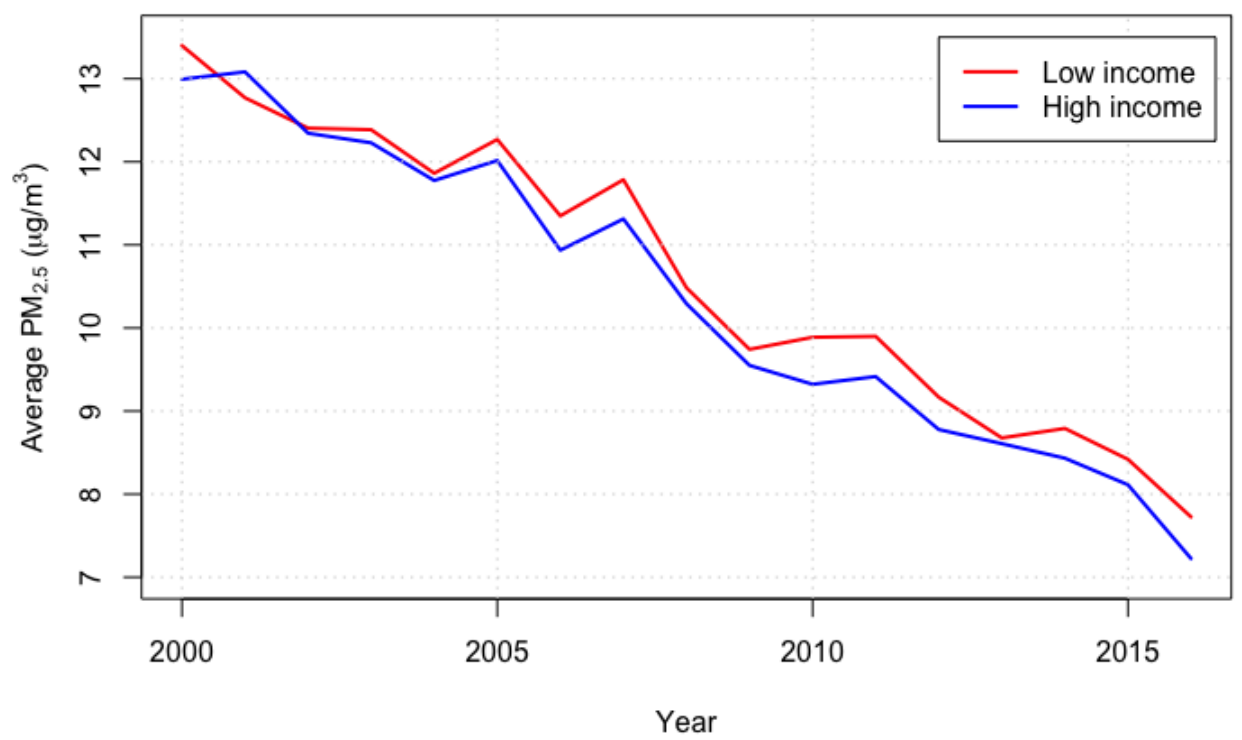

Figure A.5: The $\mathrm{PM}_{2.5}$ concentration across the income groups reveals that the low-income group is located in the most polluted areas. 
medRxiv preprint doi: https://doi.org/10.1101/2020.07.13.20152942; this version posted July 15, 2020. The copyright holder for this preprint (which was not certified by peer review) is the author/funder, who has granted medRxiv a license to display the preprint in perpetuity. It is made available under a CC-BY-NC-ND 4.0 International license .

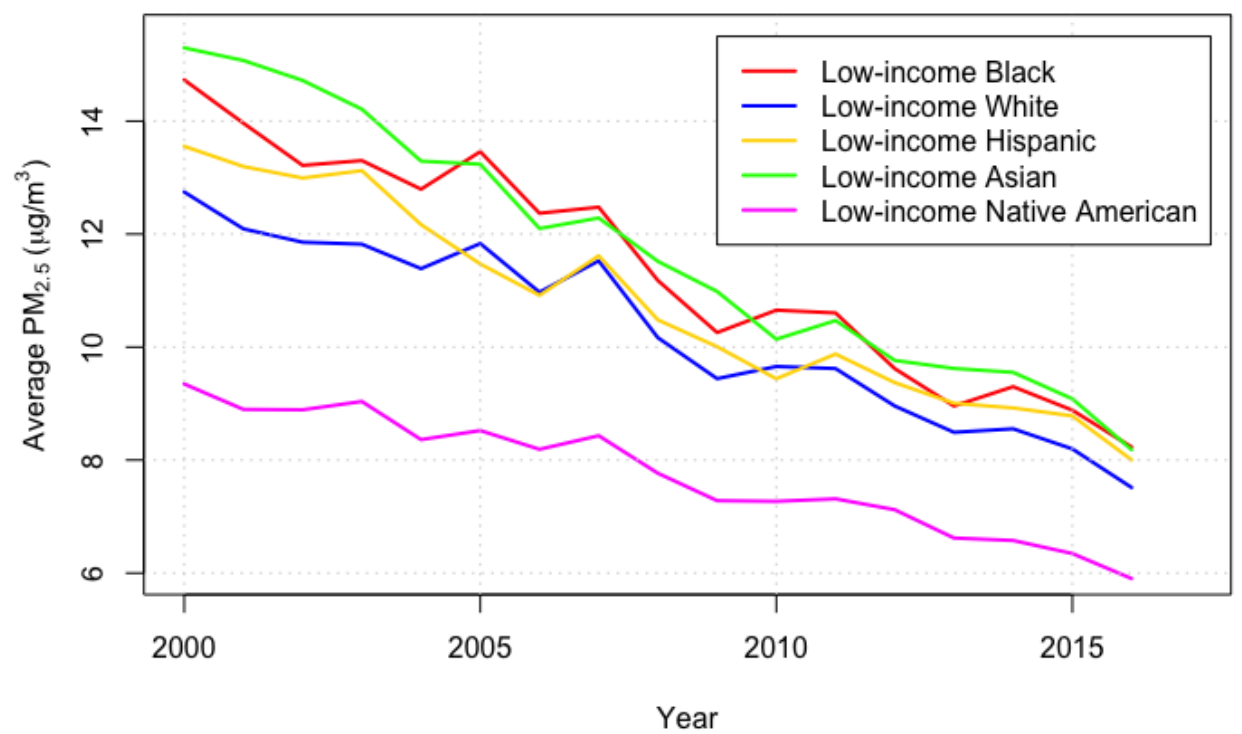

(a)

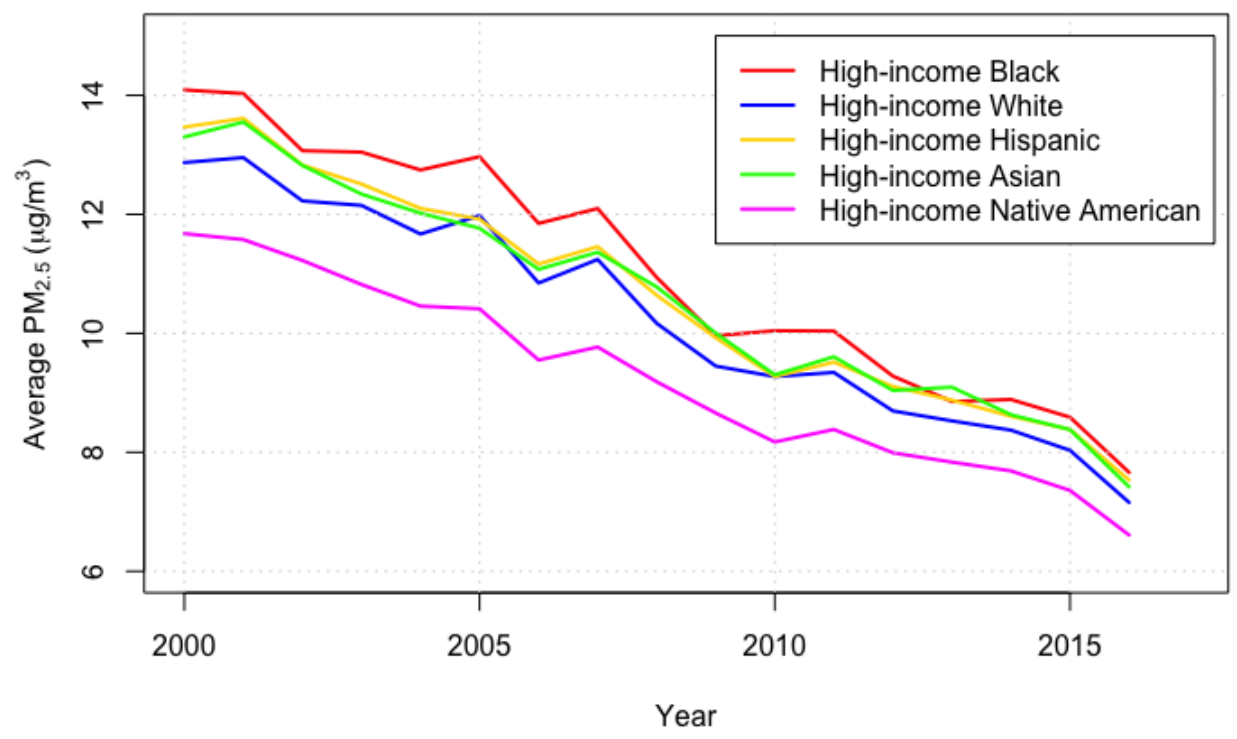

(b)

Figure A.6: (a) The population-weighted $\mathrm{PM}_{2.5}$ average concentration across the different racial/ethnic communities for 2000 to 2016 that are in the low-income group. A similar trend to that shown in Extended Data figure A.4a is seen except for the Asian population. (b) The populationweighted $\mathrm{PM}_{2.5}$ average concentration across the different racial/ethnic communities for 2000 to 2016 that are in the high-income group. A similar trend is seen in Extended Data figure A.4a. It is interesting to note that for the Native American population, low-income groups are exposed to lower concentrations of $\mathrm{PM}_{2.5}$ as compared to the high-income groups. This may be tied to the rurality vs. urbanicity of the ZCTAs, which was not included in our analysis. 
medRxiv preprint doi: https://doi.org/10.1101/2020.07.13.20152942; this version posted July 15, 2020. The copyright holder for this preprint (which was not certified by peer review) is the author/funder, who has granted medRxiv a license to display the preprint in perpetuity.

It is made available under a CC-BY-NC-ND 4.0 International license .

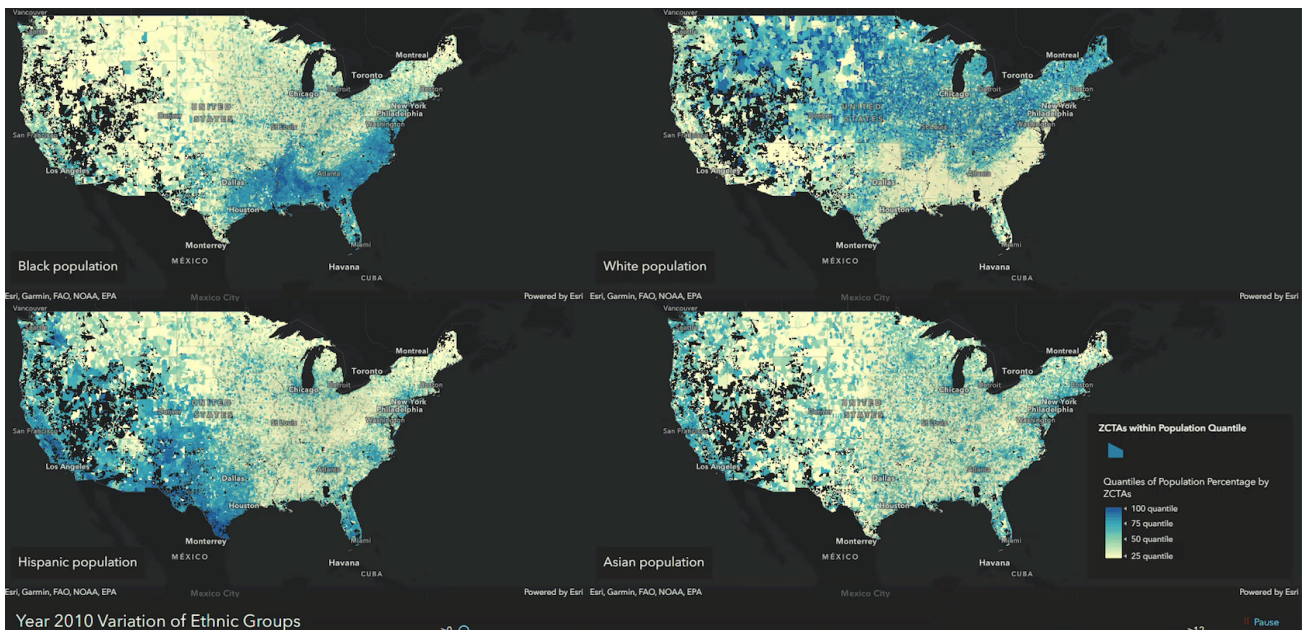

(a)

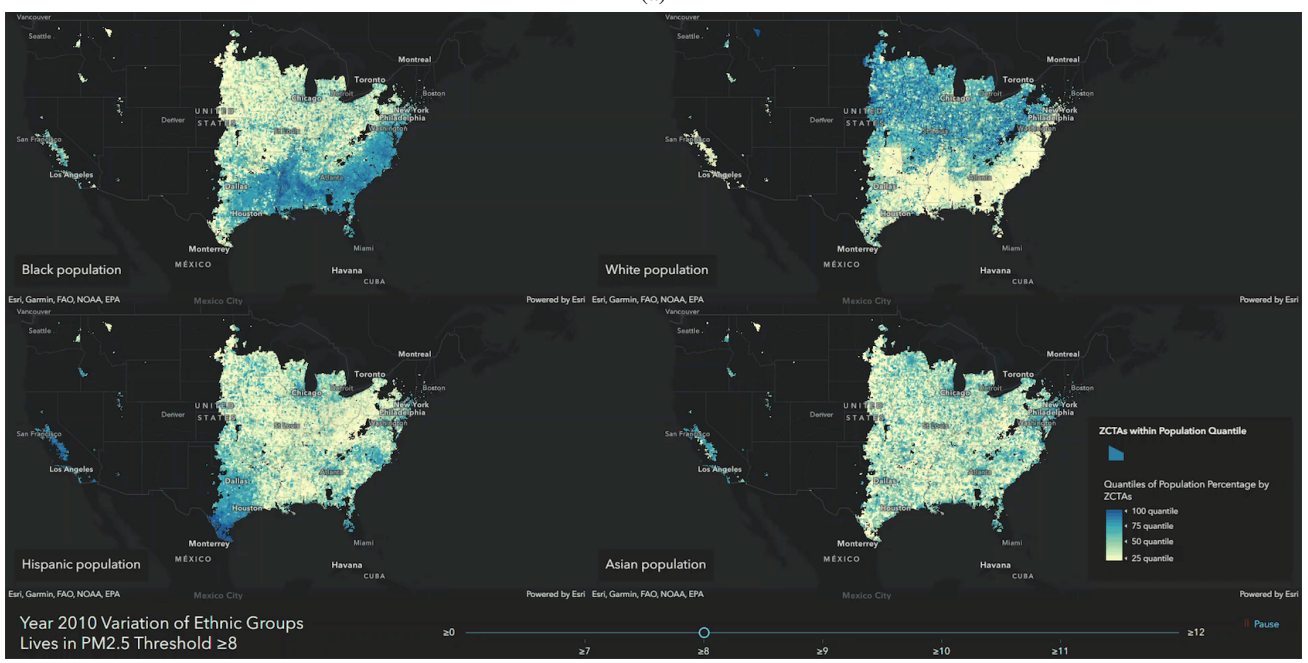

(b)

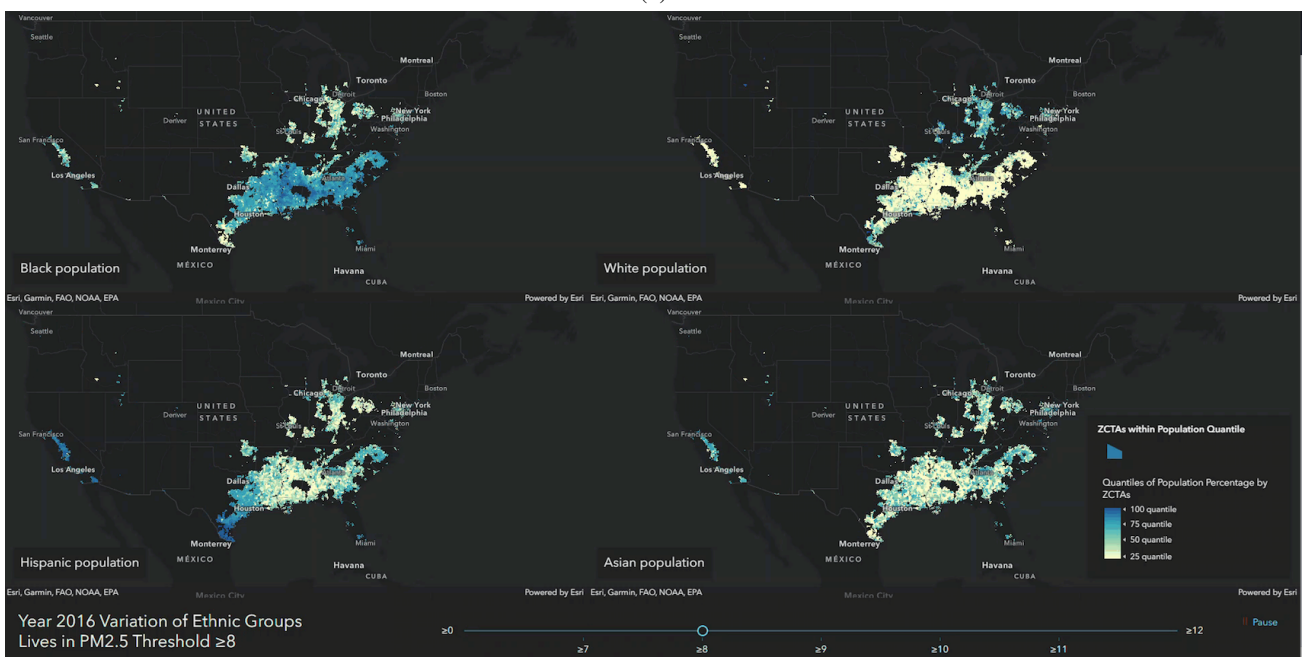

(c)

Figure A.7: The distribution of the racial/ethnic populations above a $\mathrm{PM}_{2.5}$ threshold of $8 \mu \mathrm{g} / \mathrm{m}^{3}$ for 2010 and 2016. (a) US ZCTAs for each race/ethnicity are ranked based on the ratio of the race/ethnicity population to the total ZCTA population. Dark blue indicates fractions close to 1 (ZCTAs where the corresponding race/ethnicity most lives), and light yellow indicates fractions close to 0 (ZCTAs where the corresponding race/ethnicity least lives) (b) US ZCTAs above $8 \mu \mathrm{g} / \mathrm{m}^{3}$ in 2010. (c) US ZCCTAs above $8 \mu \mathrm{g} / \mathrm{m}^{3}$ in 2016. Animation 4 shows the distribution of the different racial/ethnic communities across multiple ranges of $\mathrm{PM}_{2.5}$ concentrations for 2010 and 2016. 
medRxiv preprint doi: https://doi.org/10.1101/2020.07.13.20152942; this version posted July 15, 2020. The copyright holder for this preprint (which was not certified by peer review) is the author/funder, who has granted medRxiv a license to display the preprint in perpetuity.

It is made available under a CC-BY-NC-ND 4.0 International license .

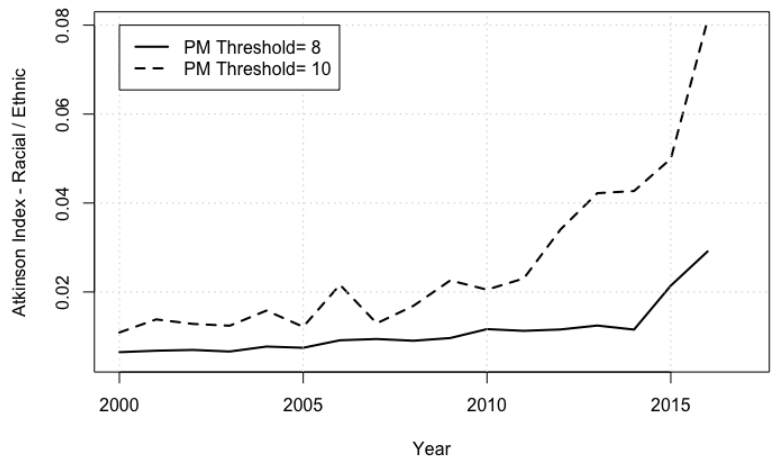

(a)

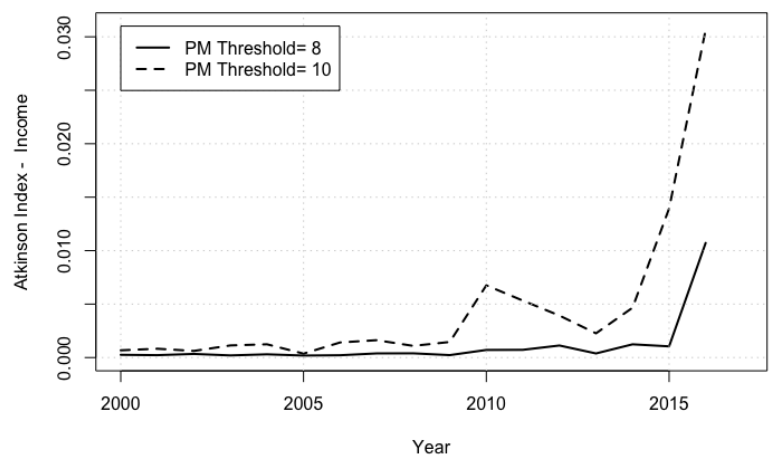

(b)

Figure A.8: Inequality measured by the Atkinson index in exposure to $\mathrm{PM}_{2.5}$ concentrations above thresholds of 8 and $10 \mu g / \mathrm{m}^{3}$ for 2000 to 2016 among (a) racial/ethnic groups (Black, White, Hispanic, Asian, and Native American) (b) and income groups (income deciles). The trend is similar to the one measured by $\mathrm{CoV}$ in figure 4, disparities in air pollution exposure among racial/ethnic groups and income groups are increasing. Further, disparities among racial/ethnic groups are higher than those among income groups, and disparities above a $\mathrm{PM}_{2.5}$ threshold of $10 \mu \mathrm{g} / \mathrm{m}^{3}$ are higher than above $8 \mu \mathrm{g} / \mathrm{m}^{3}$. The Atkinson index was computed using the inequality package "ineq" in the R software. The input is the proportion of the racial/ethnic (or income) groups living above the set $\mathrm{PM}_{2.5}$ threshold. We set the Atkinson aversion parameter $\epsilon=0.75$ [16]. 